\title{
An Investigation into Physics Teaching in Senior High Schools
}

\author{
Isaac Buabeng ${ }^{1,2, *}$, Theophilus Aquinas Ossei-Anto ${ }^{1} \&$ Joseph Ghartey Ampiah ${ }^{1}$ \\ ${ }^{1}$ University of Cape Coast, Ghana \\ ${ }^{2}$ Currently a PhD Candidate, University of Canterbury, New Zealand \\ *Corresponding author: College of Education, University of Canterbury, Christchurch 8041, New Zealand. \\ Tel: 64-223-390-7133; E-mail: isaac.buabeng@pg.canterbury.ac.nz/ibuabeng@ucc.edu.gh
}

Received: June 13, 2014

doi:10.5430/wje.v4n5p40
Accepted: August 26, 2014

Online Published: October 11, 2014

URL: http://dx.doi.org/10.5430/wje.v4n5p40

\begin{abstract}
This study sought to examine the activities that go on in physics classrooms in Senior High Schools in Ghana. Specifically, the study sought to investigate the pattern of interaction and instructional methods used for teaching physics and level of coverage of physics syllabus. The survey design was employed for the study in which questionnaire was used for data collection. Participants for the study were physics teachers and final year physics students. Findings from the study suggest that classroom interaction seemed to be mostly teacher-centered and tended not to support inquiry-based teaching and learning which is noted for promoting conceptual change and enhance performance. It is recommended among other things that physics teachers should be exposed to efficient pedagogies of teaching and presenting information to learners. The traditional way of teaching where teacher decides on what goes on in the classroom has a limited space in the $21^{\text {st }}$ century science classrooms, particularly physics.
\end{abstract}

Keywords: classroom interactions; inquiry-based teaching; pedagogy, performance; physics teachers; teaching approach

\section{Introduction}

Physics is an important subject for economic, scientific and technological development (American Physics Society, 2008; Zhaoyao, 2002). Empirical studies from the field of Physics Education Research (PER) have outlined essential suggestions about physics curriculum which are generally accepted and believed to widen the knowledge and increase the horizon of understanding of physics by learners. Among the essential suggestions are: (1) the method of teaching physics should be guided discovery instead of the traditional lecture method used in teaching the subject. This was recommended due to the fact that, learning efficiency and effectiveness take place during explanation, experimentation and discussion; (2) there should be interaction between the physics teacher and the students. In this case, it is believed that if genuine and helpful interaction exists between the teacher and students, the students will be able to inform teachers what they find difficult in physics thereby reducing the difficulties they (students) encounter (Adeyemo, 2010, p. 101). These features are essential because it is believed that if they are dully and critically followed and applied in any given situation and at any given time, teachers will be able to make physics easy to comprehend by learners (Adeyemo, 2010).

Teaching methods are the most important techniques employed by teachers to realize the objectives of a lesson (Borich, 2007; Fishburne \& Hickson, 2001). Thus, teachers of all disciplines including physics use various teaching methods for achieving lesson objectives. For physics students to achieve their full potential in schools, it would seem to be essential that teachers engage in effective teaching practices (Borich, 2007; Fishburne \& Hickson, 2001). Classroom based investigation has been able to determine effective research-based teaching practices that are related to positive learning outcomes. In a review of research studies that showed an impact on student achievement and learning, the authors summarized effective teaching methods and outlined five teaching behaviours that were supported by research and to which teachers should pay attention. These behaviours are: lesson clarity; instructional variety; teacher task orientation; engagement in the learning process; and student success rate (Borich, 1996; Hickson \& Fishburne, 2001).

The desire to pursue physics at higher levels (beyond secondary education) is influenced by the success rate and 
foundation a student receives in physics at the high school. Murphy and Whitelegg (2006) reported that in the United Kingdom prior achievement and perception of the difficulty of physics are determinants of students' decisions about whether to continue to study physics at higher levels of education. A study by Buabeng and Ntow (2010) revealed a wide range of reasons which accounted for students' negative response to physics in Ghana. Prominent among these factors were teacher factor, poor performance, perceived difficulty nature of physics and unknown career opportunities in the subject. Most of the students reported that there is a reduced interest in the subject at the Senior High School (SHS) level because the subject was poorly presented to them. Interestingly, physics teachers who participated in the study admitted that poor tuition is one of the many reasons accounting for the low interest level among students (Buabeng \& Ntow, 2010).

In Ghana, the sciences taught in SHS are biology, chemistry, physics, and integrated science. The SHS physics syllabus builds upon the foundations laid in the Junior High School (JHS) integrated science at the basic level and the integrated science at the SHS (Curriculum Research and Development Division [CRDD], 2008). The topics in the syllabus have been selected to enable the students acquire the relevant knowledge, skills and attitudes needed for tertiary level education, apprenticeship, and for life. The physics syllabus embodies a wide range of activities such as projects, experiment, demonstrations and scientific enquiry skill (CRDD, 2008). All these objectives are achieved by the teacher through giving innovative and appropriate instructions to the physics students. The physics teacher is therefore required to design teaching sequences with appropriate teaching pedagogies that has the potential to develop students' interest in the subject and their abilities to properly respond to situations the may encounter in their world of life that their knowledge in physics may be of benefit.

\section{Organization of the Senior High School Physics Syllabus}

The physics syllabus has been structured to cover three years of SHS programme. Each year's work consists of a number of sections with each section comprising a number of units. There are six main sections. Section one consists of concepts such as motion, forces and energy. Different types of motion, effects of force on motion and nature of energy are to be discussed. Topics such as thermal physics where heat and temperature are to be discussed in section two. Section three treats the concepts of waves under which characteristics of wave motion including that of light and sound waves are to be discussed. Electric and magnetic fields are treated in section four. Under this section, the major role of magnetic in instrumentation and machinery especially, in utilization of electromagnetic fields in the generation and storage of electricity are emphasized. Section five provides a guide to teaching atomic and nuclear physics where characteristics of atom, the concept of photoelectric effect and its applications, the x-rays and the peaceful uses of nuclear energy are to be discussed. Guidance in teaching electronics, where characteristics and application of semi-conductor diodes and transistors in voltage stabilization, amplification of signals and electric switching is provided in the last section (CRDD, 2008). At the end of the school year, students write a national examination, the West African Senior Secondary Certificate Examination (WASSCE) formally called Senior Secondary School Certificate Examination (SSSCE). The performance of students in the examination is used for selection into tertiary institutions.

\section{Context of the Study}

Performance of Ghanaian students in physics has been generally and consistently poor over the years. Relevant data collected on SHS students' achievement in biology, chemistry, physics and mathematics from 1993 to 2007 for PRACTICAL project plan showed an abysmal performance in physics (Anamuah-Mensah, 2007). More so, performance statistics by West Africa Examination Council (WAEC) from 2003 to 2009 show that majority of the physics candidates did not obtain the pass grade $(\mathrm{A}-\mathrm{D}$ or A1 - C6) to qualify for admission to tertiary education. The trend in performance indicates that from 2003 to 2005, out of 33,043 candidates who sat for the SSSCE physics papers 13,067 (39.5\%) obtained grade A - D. From 2006 to 2009, 41,973 (47.5\%) candidates, out of 88,294 who sat for the WASSCE physics papers, obtained grade A1 - C6 (WAEC, 2010). There was no examination in 2010 as the duration of SHS was extended from three to four years. However, in 2009 this reform was reversed again the new National Democratic Congress (NDC) government, and presently it is three years again. Comparatively, majority of the candidates performed better in biology and chemistry than in physics (WAEC, 2010).

Moreover, WAEC Chief Examiner Reports' for SHS physics indicated that performance of candidates in physics was woefully marginal or even poor (WAEC, 2005, 2006, 2008, 2009). The WAEC (2005) reported that "quite a number of candidates could not solve mathematical-related problems accurately" (p. 259). The WAEC (2006) 
painted a very gloomy picture of students' performance in physics:

One was even tempted to conclude that the standard of the paper was lower than the previous; however the performance of candidates did not lend to support this assertion. The performance could be described as woefully marginal. Only few candidates could show a good knowledge of the subject and could also apply the principles. Candidates are advised to treat physics as any science subject and learn to link it with everyday situation. Candidates' answers showed lack of understanding of the principles of the subject. (p. 104)

The WAEC (2009) report stated that "poor knowledge of subject matter, inadequate preparation and poor labelling of diagrams were some of the weaknesses that adversely affected candidates' performance (p. 376).

Over the years, students' achievement in physics has prompted educational researchers to continuously make relentless efforts at identifying mitigating factors that might account for the observed poor performance. Some research studies suggest that factors inside and outside the classroom affect students' achievement and interest. Orleans (2007) asserts that the key factor in what comes out at the end of schooling is what goes on in the classroom. Mills (as cited in Wambugu \& Changeiywo, 2008), states that teaching methods are crucial factors that affect the academic achievement of students, and no matter how well-developed and comprehensive a curriculum is, its success is dependent on the quality of the teachers implementing it (Ajaja, 2009; Ughamadu, 2005). In its attempt to help improve upon the teaching and learning of the sciences, the Ghanaian government in 1987, implemented an educational reform nationwide with the aim of providing a system of education that will serve the needs of the individual, the community and the country as a whole (Tuffour, 1989). Tuffour reported that, though there were some challenges (after almost two years of implementation) the implementation of the JHS (formally called Junior Secondary School [JSS]) science programme made a considerable success-"recruitment of teachers for all the schools, the supply of inputs (namely science syllabi, textbooks and laboratory kits), the effect of orientation for teachers and the general interest of teachers in the programme" (p. 44).

Similarly, the government of Ghana in 1995, through the Ministry of Education (MOE) and Ghana Education Service (GES) established Science Resource Centres (SRCs) in 110 SHS spread throughout the country. Each centre was intended to be used by a number of SHS known as satellite schools within a 40-kilometre radius depending on the population of the schools. This project was initiated to help bridge the gap between schools with well-resourced science laboratories (both human and material resources) and those with little or no resources, hence ensuring equity in students' learning across the rural-urban divide (Ministry of Education, 2004). The SRCs were equipped with basic science equipment including modern electronic devices and computers to be used in the teaching and learning of science, including physics, and thereby improving students' performance. In addition, buses were provided to all SRCs for use by satellite schools (Ampiah, 2004). After almost two decades of its (SRCs) implementation, performance of students in the science, with physics in particularly, has not been any better as indicated earlier. It is not clear where the responsibility lies as little is known about physics teaching in the SHS. It would be interesting, therefore, to investigate whether factors such as teacher quality, teaching methodology, teachers' and students' attitude toward physics, support system among many others have any effect on students' interest and hence their performance. This study sought to investigate what kind of practices exists in relation to physics classrooms of SHS in Ghana. The specific research questions addressed in this report include:

1. What is the level of qualification and experience of physics teachers in SHS?

2. What is the pattern of interaction in physics classroom?

3. What instructional methods are used for teaching physics?

4. What is the extent of coverage of contents of physics syllabus?

\section{Conceptual Framework}

Studies have shown that instructional practices depend on what teachers bring to the classroom and that professional competence is a crucial factor in classroom and school practices (Campbell, McNamara, \& Gilroy, 2004; Kunter \& Baumert, 2006). Teaching practices which are related to effective classroom learning and student outcomes have also been described and shown to have a positive impact on student achievement (Scheerens, 2009). These aforementioned practices can be said to be embedded in a specific instructional model carefully designed to impact on student learning. The study therefore uses an instructional quality model, adapted from Teaching and Learning International Survey (TALIS) (Scheerens, 2009). The framework is represented diagrammatically in Figure 1. 


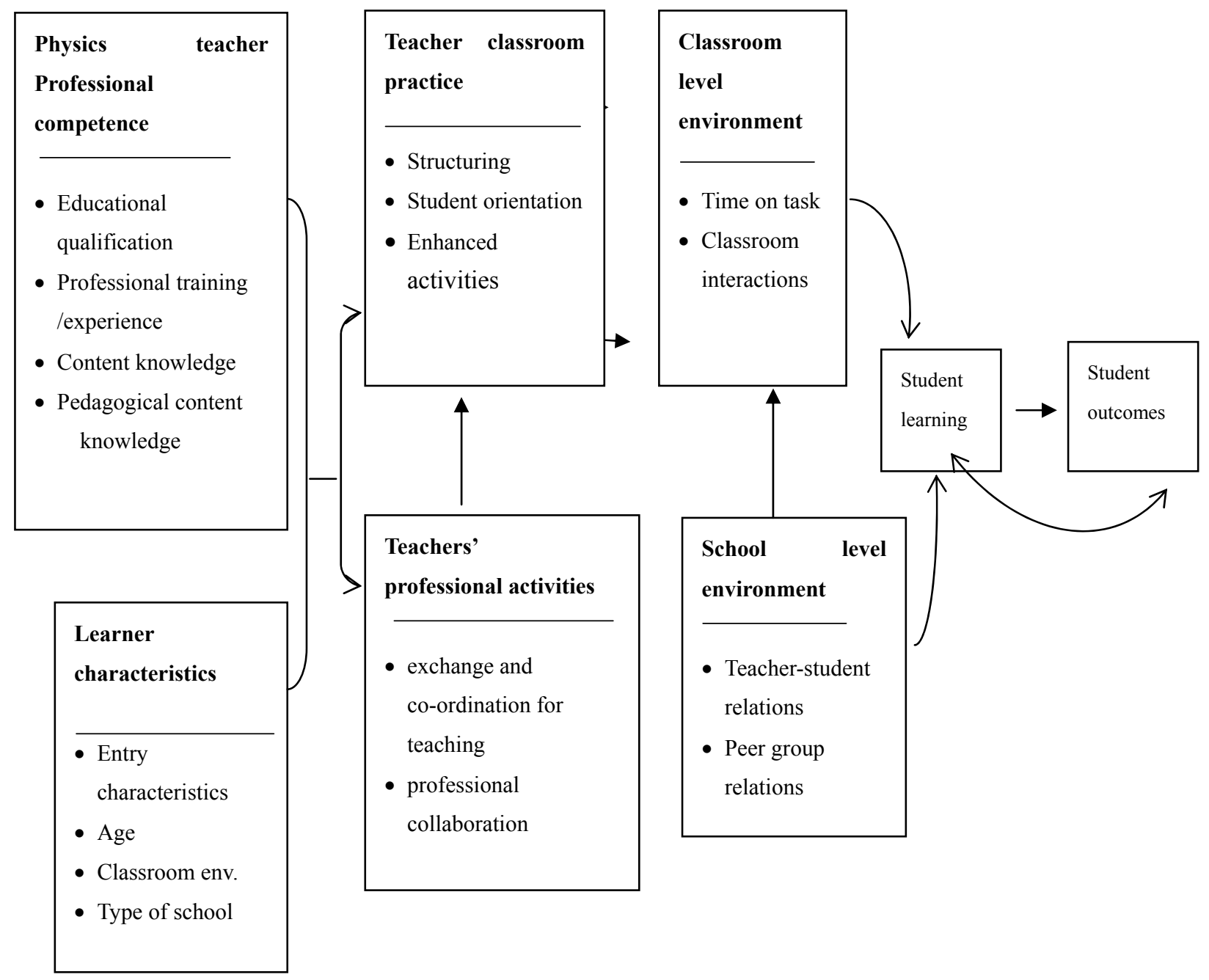

Figure 1. The Conceptual Framework (Instructional Quality Model)

Figure 1 shows the relationship of variables for determining students' achievement. Learning outcomes are influenced by various factors which include: teacher professional competence; learner characteristics; classroom level environment; school level environment; and teacher characteristics as shown. Teacher professional competence determines the academic and professional qualifications of the teacher, content knowledge and teaching approach/pedagogy a teacher uses and how effective the teacher will use the approach. The learners' age determines what they are taught and what they can learn and the type of school (public or private) as teaching environment affects the learning outcomes (Scheerens, 2009).

As emphasized by (Darling-Hammond, 2000; Darling-Hammond, Berry, \& Thoreson, 2001; Goldhaber \& Anthony, 2003), a contemporary view of teaching also includes professional activities on the school level which have greater impact on student achievement. Again, TALIS uses time on task (i.e. the proportion of lesson time that is actually used for teaching and learning and how much tasks are covered within a period) as another basic indicator for the quality of the teaching and learning environment. Also, classroom climate (teacher and students' relationships) is used for its strong influence on cognitive and motivational aspects of student learning (Scheerens, 2009). The model described above illustrates the relations between instructional practices and good students' outcomes. These and many others are variables which need to be investigated as far as teaching and learning of physics is concerned. 


\section{Methodology}

\subsection{Research Design}

The survey design was employed for this study. This design was considered most appropriate since questionnaire was the main instrument used for data collection from the segment of the population of interest. Survey is more economical since many subjects can be studied at the same time (Mitchell \& Jolley, 2004). Also, findings from the study can be generalized for the entire population.

\subsection{Population}

Ghana is divided into 10 regions for administrative purposes and has a total of 254 public and 17 private SHS at the time of the study. These schools were those registered with WAEC, and offering elective science subjects (Ghana Education Service, 2009). The population for the study comprised physics teachers and final year students offering physics in the public SHS in Ashanti Region of Ghana. Ashanti Region was chosen because the region has greater number of SHS offering elective science programme including physics (Ghana Education Service, 2009). It is also a cosmopolitan region and many people educate their children there. Final year students were targeted because these students would have experienced physics teaching for almost three years and would therefore be in position to share their experiences in relation to the teaching and learning of physics.

\subsection{Sample and Sampling Technique}

Preliminary situational analysis of documents, at the time of the study, showed that Ashanti Region had 96 SHS of which 53 offered physics. Of the 53 schools, 17 were schools with a Science Resource Centre (SRC) and 37 were satellite schools. Thus the schools were initially put into two strata-SRC and satellite schools. Simple random sampling was then used to select a total of nine schools, three SRC schools and six satellite schools. In each school, the "table for estimating sample size from a given population" developed by Krejcie and Morgan (as cited in Sarantakos, 2005, p. 173) was used as a guide to select the students' sample sizes for the study. In all cases, the simple random technique was employed to select students.

The sample size for the teachers comprised all physics teachers at post in the schools that were sampled for the study. In all, there were 21 physics teachers -5 from schools with SRC and 16 from satellite school. Majority of the teachers (18 representing $85.7 \%)$ were males with the remaining three (14.3\%) being females. The teachers who participated in the study were generally in their youth as 19 of them were less than 40 years. Only two teachers were above 50 years. The sample size for the students was 326 with 196 (60.1\%) males and 130 (39.9\%) females respectively.

\subsection{Instrument}

Questionnaire was the main instrument used for data collection for the study. Two forms of both open and closed ended questionnaire (teachers' questionnaire and students' questionnaire) were developed and used for data collection. The items were adapted from Ajaja (2009) and modified to suit the purpose and context of this study. The instruments were reviewed by experts in the field to ensure face and content validity after which they were pre-tested in similar schools (two satellite schools and one SRC school) in Central Region to estimate their reliabilities. The items were subjected to item analysis in order to identify those whose removal or modification will enhance the internal consistency of the instruments (Pallant, 2007). The Statistical Package for Services and Solutions (SPSS) was used to determine the Cronbach alpha coefficient values for the instruments. Alpha values of 0.87 and 0.76 were obtained for students' and teachers' questionnaires respectively. The responses for the open ended items indicated that participants understood the questions and that the wording of the items was appropriate.

\subsection{Data Collection Procedure}

Collection of data for the study started with negotiating access to the schools. Permission was sought from the school authorities in the region. An official letter of introduction was obtained from the Regional Director of Education (GES) to visit the schools that were selected for the study. In each school visited, the students' questionnaire was administered to the final year students. Students were made to complete the questionnaire at a sitting. The completed questionnaires were collected the same day. The teachers' questionnaire was also administered to the physics teachers in all the nine SHS selected for the study. In some of the schools questionnaires were left with the head of physics department to be given to teachers who were not at post. As much as we could, physics teachers' questionnaires were collected after the third day. However, collection of teachers' questionnaire continued for three weeks after which cases of non-responses were abandoned. This resulted in a return rate of $77.8 \%$. All responses (from both teachers and students) were scored, analysed and presented in tables. 


\section{Results and Discussion}

\subsection{Teacher Qualification}

Academic qualification of the SHS physics teachers verses teacher quality was first examined. Research findings confirm teacher quality as one and most influential factor on students' achievement and many a time, academic preparation of teachers, type of certificate, professional learning and years of teaching experience are taken as indicators of teacher quality (Darling-Hammond, 2000; Darling-Hammond et al., 2001; Goldhaber \& Anthony, 2003). In this report, only academic qualification (types of certificate) and teaching experience of the teachers are discussed. Academic preparation of physics teachers is another report on its own which is forthcoming. The SHS physics teachers' level of academic attainment and teaching experience are presented in Table 1 and Table 2 respectively.

Table 1. Level of Academic Attainment of Physics Teachers

\begin{tabular}{lll}
\hline Qualification & $\mathrm{N}$ & $\%$ \\
\hline MPhil & 2 & 9.3 \\
MSc & 3 & 14.3 \\
BSc & 9 & 42.9 \\
BEd & 7 & 33.3 \\
\hline Total & 21 & 100.0
\end{tabular}

As presented in Table 1, all teachers had at least four years of tertiary education. About $43 \%$ had Bachelor of Science degree whereas $33.3 \%$ had Bachelor of Education degree. Five teachers had master's degree-two Master of Philosophy degrees and three Master of Science degrees. There was no teacher with a doctoral degree. When asked to indicate other professional qualifications acquired if academic certificate was not in education, only one teacher indicated that he/she had completed Post Graduate Diploma in Education (PGDE). Diploma in Project Management and Journalism were also mentioned by few of the teachers as other professional qualifications obtained.

Table 2. Teachers' Years of Teaching Experience

\begin{tabular}{lll}
\hline $\begin{array}{l}\text { Range of teaching } \\
\text { experience (in years) }\end{array}$ & $\mathrm{N}$ & $\%$ \\
\hline $1-5$ & 11 & 52.4 \\
$6-10$ & 7 & 33.3 \\
$11-15$ & 1 & 4.8 \\
$15+$ & 2 & 9.5 \\
\hline Total & 21 & 100.0 \\
\hline
\end{tabular}

Data in Table 2 indicate that only one-seventh of teachers (14.3\%) had teaching experience above 10 years. Majority of the teachers $(52.4 \%)$ had teaching experience less than six years.

Even though all the teachers had at least four years of tertiary education, it can be inferred from Table 1 that majority of SHS physics teachers have their qualifications not in education. What it means is that most of the physics teachers are not trained as professional teachers but have been recruited by GES to teach, a phenomenon commonly practiced in Ghana. That is, university graduates without qualifications in education are recruited to teach in SHS and are classified as non-professional teachers (Ministry of Education, 2012). Although the recruited teachers may have the content knowledge and competent in subject matter, same cannot be said of their pedagogical knowledge and relevant skill-set to promote effective delivery of instruction. As noted by (Darling-Hammond, 2000; McDermott \& Shaffer, 2000; Orleans, 2007), to produce larger student achievement gains, one must be competent in both subject matter content and pedagogical skills. The data on teachers' years of teaching experience in relation to the age distribution as shown in Table 2 also suggest that most of the SHS may not have experienced physics teachers at post. It pre-supposes that most of the teachers teach for few years and leave the classroom for other jobs, perhaps more lucrative jobs other than teaching. Though in some countries teachers are among the highly paid workers the situation in Ghana is the exact opposite. It is therefore not surprising that some of these physics teachers have undertaken Diploma in Project Management, a requirement by many of the Non-Governmental Organisations (NGOs) who are noted of paying 'good' salaries to their employees. 


\subsection{Pattern of Interaction and Instructional Method}

In this section, interactions and instructional method used in physics classrooms are presented and discussed from the viewpoint of the teachers and students.

Table 3. Pattern of Interaction in Physics Classrooms

\begin{tabular}{lcccc}
\hline & \multicolumn{2}{c}{ Teachers' response } & \multicolumn{2}{c}{ Students' response } \\
\cline { 2 - 5 } Pattern of interaction & $\mathrm{N}$ & $\%$ & $\mathrm{~N}$ & $\%$ \\
\hline $\begin{array}{l}\text { Student-centered (students have a } \\
\text { say in what happens) }\end{array}$ & 18 & 85.7 & 73 & 22.4 \\
$\begin{array}{l}\text { Teacher centered (teacher decides } \\
\text { what happens) }\end{array}$ & 3 & 14.3 & 253 & 77.6 \\
\hline Total & 21 & 100.0 & 326 & 100.0
\end{tabular}

Table 3 shows the pattern of interaction in the physics classrooms. As almost all the teachers said the pattern of interaction was student-centered, majority of the students (77.6\%) disagreed and indicated that pattern of interaction was mostly teacher-centered and that teachers always decide what goes on in the classroom. This was followed up with an item on teaching methods employed by the teachers. Both teachers' and students' responses are compared in Table 4.

Table 4. Methods of Instruction used in Physics Classrooms

\begin{tabular}{lllll}
\hline \multirow{2}{*}{ Instructional method } & \multicolumn{2}{c}{ Teachers' response } & \multicolumn{2}{c}{ Students' response } \\
\cline { 2 - 5 } & $\mathrm{N}$ & $\%$ & $\mathrm{~N}$ & $\%$ \\
\hline Lecture & 6 & 28.6 & 141 & 43.3 \\
Interactive demonstration & 3 & 14.3 & 54 & 16.6 \\
Discussion & 9 & 42.9 & 118 & 36.2 \\
Hands-on activity & 1 & 4.8 & 7 & 2.1 \\
Others (lecture \& discussion) & 2 & 9.5 & 6 & 1.8 \\
\hline Total & 21 & 100.0 & 326 & 100.0
\end{tabular}

As shown in Table 4, the dominant teaching methods in most physics classroom were discussion and lecture methods. Interactive demonstration and hands-on activity methods which are inquiry in nature and students' directed were rarely used by the teachers. Likewise, when asked to indicate other methods used, only a few proportion of the teachers $(4.8 \%)$ used a combination of lecture and discussion methods. Additionally, both teachers and students were asked to indicate the extent to which student-centered and teacher-centered approaches are used in the physics classroom. The mean, standard deviation and percentage responses by teachers and students are presented in Table 5 .

Table 5. Mean, Standard Deviation and Percentage Responses on Teacher and Student-Centered Approaches

\begin{tabular}{|c|c|c|c|c|c|c|}
\hline \multirow[b]{2}{*}{ Statement } & \multicolumn{4}{|c|}{ Responses by teachers $(\mathrm{N}=21)$} & \multirow[b]{2}{*}{ Mean } & \multirow[b]{2}{*}{ Std. dev } \\
\hline & Daily & Weekly & Monthly & Rarely & & \\
\hline $\begin{array}{l}\text { I use student-centered method of } \\
\text { teaching in my physics classroom }\end{array}$ & 19.0 & 42.9 & 9.5 & 28.6 & 2.5 & 1.1 \\
\hline $\begin{array}{l}\text { I use teacher-centered method of } \\
\text { teaching in my physics classroom }\end{array}$ & 33.3 & 9.5 & 14.3 & 42.9 & 2.7 & 1.4 \\
\hline \multicolumn{7}{|l|}{ Responses by students $(\mathrm{N}=326)$} \\
\hline $\begin{array}{l}\text { Teacher uses student-centered } \\
\text { method of teaching in my physics } \\
\text { classroom }\end{array}$ & 13.8 & 16.7 & 5.4 & 64.1 & 2.8 & 1.3 \\
\hline $\begin{array}{l}\text { Teacher uses teacher-centered } \\
\text { method of teaching in my physics } \\
\text { classroom }\end{array}$ & 64.7 & 17.5 & 3.1 & 14.7 & 1.9 & 1.2 \\
\hline
\end{tabular}


It can also be inferred from Table 5 that student-centered approach was not a daily teaching method in the physics classrooms. Only about $19.0 \%$ of the teachers said they used the method as a daily teaching method. More than one-fourth of the teachers rarely used it. The rest (which happened to be the majority), either used it weekly or monthly. Students' responses confirm that student-centered approach was used once in a blue moon and that physics classrooms were dominated by teacher-centered method.

The findings as indicated in Table 5 show that pattern of interaction in most physics classrooms is the teacher initiated and dominated teacher-student interaction. This is not in consonant with international standards which recommend that teachers of science plan inquiry-based programmes for their students and should also interact with students to focus and support their inquiries, recognise individual differences and provide opportunities for all students to learn (Bencze, Alsop, \& Bowen, 2009; Bybee, Carlson-Powell, \& Trowbridge, 2008; Centre for Inspired Teaching, 2008). The findings also fall short to the recommendation of teaching for effective learning (learning with understanding) where students take responsibility of their own learning through active construction and reconstruction of their own meanings for concepts and phenomena (Borich, 2007; Brass, Gunstone, \& Fensham, 2003). The findings of teacher initiated and dominated teacher-student interaction and lecture method as major method of teaching confirm with Ajaja (2009) who made similar findings in different public schools in Delta State, Nigeria.

\subsection{Coverage of Content of Physics Syllabus}

As mentioned earlier the physics syllabus for the SHS has been organized to cover three years of SHS programme with each year's work involving a number of sections and with each section comprising a number of units. Students are examined at the end of the third year for placement into tertiary institutions. The extent to which physics teachers cover the content materials in the syllabus upon which their students are examined is presented and discussed below. When students were asked to indicate which of the science subjects (biology, chemistry, and physics) do teachers cover the greatest content material in each term of the academic year, Table 6 shows that physics was the least covered subject. Content materials in biology were most covered followed by chemistry.

Table 6. Coverage of Content Material for Biology, Chemistry, and Physics

\begin{tabular}{lll}
\hline Subject & Responses \\
\cline { 2 - 3 } & $\mathrm{N}$ & $\%$ \\
\hline Biology & 196 & 60.1 \\
Chemistry & 95 & 29.1 \\
Physics & 35 & 10.7 \\
\hline Total & 326 & 100.0 \\
\hline
\end{tabular}

The extent of coverage of physics content per an academic term is shown in Table 7. In the views of the physics teachers, the level of coverage of content for an academic term was between 80 and 90 percent with majority (42.9\%) covering about $80 \%$ content materials. About $24.0 \%$ of the teachers were able to cover up to 70 percent and only a few $(9.5 \%)$ covered less than 50 percent. Among the 21 teachers who participated in the study, only one (4.8\%) mentioned he/she had 100 percent coverage of the scheme for the term.

Table 7. Extent of Coverage of Physics Content

\begin{tabular}{lllll}
\hline $\begin{array}{l}\text { Extents of coverage } \\
\text { (in \%) }\end{array}$ & \multicolumn{2}{c}{ Responses by teachers } & \multicolumn{2}{c}{ Responses by students } \\
\cline { 2 - 5 } & $\mathrm{N}$ & $\%$ & $\mathrm{~N}$ & $\%$ \\
\hline 100 & 1 & 4.8 & - & - \\
90 & 4 & 19.0 & 17 & 5.2 \\
80 & 9 & 42.9 & 31 & 9.5 \\
70 & 2 & 9.5 & 50 & 15.3 \\
60 & 2 & 9.5 & 101 & 31.0 \\
50 & 1 & 4.8 & 111 & 34.0 \\
$<50$ & 2 & 9.5 & 16 & 4.9 \\
\hline Total & 21 & 100.0 & 326 & 100.0 \\
\hline
\end{tabular}


However, majority of students' responses $(65.0 \%)$ as indicated in the table show that up to about 60 percent content materials were covered by their teachers per an academic term. None of the students mentioned 100 percent coverage of content by the teacher. These responses by the students again contradict those by their teachers.

Judging from both responses (teachers and students), one will be not be wrong to infer that a reasonable percentage of physics content materials are left uncovered before students sit for their final examination. In many African countries, and Ghana in particular, public school teachers would normally embark on strikes and sometimes protracted ones, just to press home their demands. The non-coverage of this reasonable amount of physics content materials can be explained by some of these strikes and many other factors which need to be investigated. Similar findings were discovered by Ajaja (2009) in Delta State, Nigeria, where greater portions of science content materials are not covered due to protracted strikes by teachers in the public schools.

\section{Conclusion}

The findings from the study indicate that students' poor achievement in physics can be attributed to a number of reasons. First and foremost, most of the physics teachers do not have academic qualification and/or certificate in education. What this means is that these teachers may lack the pedagogical knowledge and unfamiliar with the teacher actions that support and promote student learning. Second, classroom interaction-the disposition of teachers and students during instruction dialogue, seemed to be mostly teacher-centered and tended not to support inquiry-based teaching and learning which is noted for promoting conceptual change and enhance performance. The traditional way of teaching where teacher decides on what goes on in the classroom has a limited space in the $21^{\text {st }}$ century science classrooms, particularly physics.

In addition, in every academic term, teachers seem not to cover most of their teaching units or schemes of work for the term. This may have a ripping effect on student performance. The examination body, WAEC, may not know and in fact, does not consider which areas in the physics syllabus are covered and which are not. At the end of the school year, students are examined holistically on the teaching syllabus.

\section{Recommendation}

From the findings of the study it is recommended that policies adopted by the state regarding teacher recruitment to the SHS should be re-visited. The situation in current policy where university graduates without certificate in education are recruited to teach in SHS but are classified as non-professional teachers can be reviewed for science teachers if not all teachers. For example, the non-professional teachers should be made to acquire a certificate in education once recruited. At the moment these teachers are only encouraged to undertake professional courses; it is not mandatory. Again, professional learning can make an important difference in the qualifications, experiences and capacities that teachers bring on board. Ministry of Education and GES could equally institute a professional development programmes on regular and frequent basis for these teachers to expose them to the current methods of teaching and presenting information to learners. It behoves these organisations to enact and, as well, implement policies to enhance the quality of teaching and learning in the schools.

The contradictions between teachers and students responses as highlighted in this report should be investigated further. Anecdotal evidence shows that, on the average most teachers would paint a good picture of themselves than to highlight on their deficiencies. In view of this, it is recommended that the study should be replicated in other regions of Ghana using a mixed method methodology. For example, classroom observation and/or interview could be used to substantiate the findings from the survey data.

\section{Acknowledgement}

Parts of this study were supported by University of Cape Coast Research Grant, support which we gratefully acknowledge. 


\section{References}

Adeyemo, S. (2010). Teaching/learning physics in Nigerian secondary school: The curriculum transformation, issues, problems and prospects. International Journal of Educational Research and Technology, 1(1), 99-111.

Ajaja, O. P. (2009). Evaluation of science teaching in secondary schools in Delta state: Teaching of the sciences. International Journal of Science Education, 1(2), 119-129.

American Physics Society. (2008). Why study physics? Retrieved May 25, 2013, from http://www.aps.org/programs/education/whystudy.cfm

Ampiah, J. G. (2004). An investigation into science practical work in senior secondary schools: Attitudes and perceptions. (PhD Thesis), University of Cape Coast, Cape Coast.

Anamuah-Mensah, J. (2007). Relevant data collected for PRACTICAL project plan. Paper presented at the PRACTICAL Project Workshop, Elmina.

Bencze, J. L., Alsop, S., \& Bowen, G. M. (2009). Student-teachers' inquiry-based actions to address socioscientific issues. Journal of Activist Science \& Technology Education, 1(2), 78-112.

Borich, G. D. (2007). Effective teaching methods: Research-based practice: Prentice Hall.

Brass, C., Gunstone, R., \& Fensham, P. (2003). Quality learning of physics: Conceptions held by high school and university teachers. Research in Science Education, 33(2), 245-271. http://dx.doi.org/10.1023/A:1025038314119

Buabeng, I., \& Ntow, D. F. (2010). A Comparison study of students' reasons/views for choosing/not choosing physics between undergraduate female non-physics and female physics students at University of Cape Coast. International Journal of Research in Education, 2(2), 44-53.

Bybee, R. W., Carlson-Powell, J., \& Trowbridge, L. W. (2008). Teaching secondary school science: Strategies for developing scientific literacy (9th ed.). Merril, New Jersey: Prentice Hall.

Campbell, A., McNamara, O., \& Gilroy, P. (2004). Practitioner research and professional development in education: SAGE Publications Limited.

Centre for Inspired Teaching. (2008). Inspired issue brief: Inquiry-based teaching. Retrieved May 21, 2013, from www.inspiredteaching.org

Curriculum Research and Development Division [CRDD]. (2008). Teaching syllabus for physics (Senior High School). Accra: Ghana Education Service.

Darling-Hammond, L. (2000). Teacher quality and student achievement: A review of state policy evidence. Education policy analysis archives, 8(1), 1-15.

Darling-Hammond, L., Berry, B., \& Thoreson, A. (2001). Does teacher certification matter? Evaluating the evidence. Educational Evaluation \& Policy Analysis, 23(1), 57-77. http://dx.doi.org/10.3102/01623737023001057

Fishburne, G., \& Hickson, C. (2001). Learning through effective teaching: Research studies in physical education. Learning for the future: Proceedings of the Learning Conference 2001. Paper presented at the eighth annual International Literacy and Education Research Network Conference on Learning. Spetses, Greece.

Ghana Education Service. (2009). Register of programmes for senior high schools/technical/vocational institutions. Accra: Author.

Goldhaber, D., \& Anthony, E. (2003). Teacher quality and student achievement. Urban diversity series. New York N. Y.: Eric Clearinghouse on Urban Education.

Kunter, M., \& Baumert, J. (2006). Who is the expert? Construct and criteria validity of student and teacher ratings of instruction. Learning Environments Research, 9(3), 231-251. http://dx.doi.org/10.1007/s10984-006-9015-7

McDermott, C. L., \& Shaffer, P. S. (2000). Preparing teachers to teach physics and physical science by inquiry. Physics Education, 35(6), 411-416. http://dx.doi.org/10.1088/0031-9120/35/6/306

Ministry of Education. (2004). Development of education: National report of Ghana. Accra: Ghana Education Service.

Ministry of Education. (2012). Pre-tertiary teacher professional development and management in Ghana: Policy framework. Accra: Ghana Education Service. 
Mitchell, M., \& Jolley, J. (2004). Chapter 7: survey research. Research Design Explained, 5th edn (Mitchell M \& Jolley J eds). Wadsworth/Thomson Learning, Belmont, CA, 179-214.

Murphy, P., \& Whitelegg, E. (2006). Girls in the physics classroom: A review of the research on the participation of girls in physics. Milton Keynes: The Open University.

Orleans, A. V. (2007). The condition of secondary school physics education in the Philippines: Recent developments and remaining challenges for substantive improvements. The Australian educational researcher, 34(1), 33-54. http://dx.doi.org/10.1007/BF03216849

Pallant, J. (2007). SPSS survival manual: A step by step guide to data analysis using SPSS (3rd ed.). Bershire, UK: Open University Press.

Sarantakos, S. (2005). Social research (3rd ed.). New York: Palgrave Macmillan

Scheerens, J. (2009). Teachers' professional development: Europe in international comparison. A secondary analysis based on the TALIS dataset. The Netherlands: University of Twente.

Tuffour, J. K. (1989). Implementation of the JSS science programme in Cape Coast district: A case study. Journal of Ghana Association of Science Teachers, 1(1), 38-46.

Ughamadu, K. A. (2005). Curriculum: Concept, development and implementation. Onitsha Emba Printing and Publishing Company Ltd.

WAEC. (2005). Chief examiner report. Accra: WAEC Press.

WAEC. (2006). Chief examiner report. Accra: WAEC Press.

WAEC. (2008). Chief examiner report. Accra: WAEC Press.

WAEC. (2009). Chief examiner report. Accra: WAEC Press.

WAEC. (2010). Chief examiner report. Accra: WAEC Press.

Wambugu, P. W., \& Changeiywo, J. M. (2008). Effects of mastery learning approach on secondary school students' physics achievement. EURASIA Journal of Mathematics, Science \& Technology Education, 4(3), 293-302.

Zhaoyao, M. (2002). Physics education for the 21st century: Avoiding a crisis. Physics Education, 37(1), 18-24. 